\title{
Regulation of IFN response gene activity during infliximab treatment in rheumatoid arthritis is associated with clinical response to treatment
}

\author{
Lisa GM van Baarsen 1,2, Carla A Wijbrandts33, François Rustenburg1', Tineke Cantaert³, Tineke CTM van der Pouw \\ Kraan ${ }^{4}$, Dominique L Baeten ${ }^{3}$, Ben AC Dijkmans ${ }^{5}$, Paul P Tak ${ }^{3}$ and Cornelis L Verweij*1,5
}

\begin{abstract}
Introduction: Cross-regulation between TNF and type I IFN has been postulated to play an important role in autoimmune diseases. Therefore, we determined the effect of TNF blockade in rheumatoid arthritis (RA) on the type I IFN response gene activity in relation to clinical response.

Methods: Peripheral blood from 33 RA patients was collected in PAXgene tubes before and after the start of infliximab treatment. In a first group of 15 patients the baseline expression of type I IFN-regulated genes was determined using cDNA microarrays and compared to levels one month after treatment. The remaining 18 patients were studied as an independent group for validation using quantitative polymerase chain reaction (qPCR).

Results: Gene expression analysis revealed that anti-TNF antibody treatment induced a significant increase in type I IFN response gene activity in a subset of RA patients, whereas expression levels remained similar or were slightly decreased in others. The findings appear clinically relevant since patients with an increased IFN response gene activity after antiTNF therapy had a poor clinical outcome. This association was confirmed and extended for an IFN response gene set consisting of OAS1, LGALS3BP, MX2, OAS2 and SERPING1 in five EULAR good and five EULAR poor responders, by qPCR.

Conclusions: Regulation of IFN response gene activity upon TNF blockade in RA is not as consistent as previously described, but varies between patients. The differential changes in IFN response gene activity appear relevant to the clinical outcome of TNF blockade in RA.
\end{abstract}

\section{Introduction}

Cytokines are key regulators of pathogenic processes in a variety of inflammatory and autoimmune diseases. Major roles for both tumor necrosis factor (TNF) and type I interferon (IFN) have previously been demonstrated. Type I IFN (IFN $\alpha / \beta)$ plays an important role in systemic lupus erythematosus (SLE) [1]. Evidence for the role of IFN in SLE came from the induction of disease during IFN $\alpha / \beta$ treatment and circulating IFN inducers $[2,3]$. Type I IFN activity in SLE is associated with disease severity [1]. TNF was the first cytokine convincingly demonstrated to contribute to chronic inflammation in several autoimmune diseases, including rheumatoid arthritis (RA) and Crohn disease [4]. Accordingly, block-

\footnotetext{
* Correspondence: c.verweij@vumc.nl

1 Department of Pathology, VU University Medical Center, De Boelelaan 1118 $1081 \mathrm{HZ}$, Amsterdam, The Netherlands
}

ade of TNF activity has proven to be highly beneficial in the treatment of these diseases $[5,6]$.

Blockade of TNF reduces the acute-phase reaction and decreases the local and systemic levels of inflammatory mediators in patients with RA (reviewed in [7]). However, the improvement varies between patients, and approximately $30 \%$ of RA patients fail to respond to this therapy. It has been suggested that TNF suppresses IFN $\alpha$ production by inhibiting both the generation of plasmacytoid dendritic cells (pDCs) and their IFN $\alpha$ secretion $[8,9]$. Accordingly, it was shown that TNF blockade in systemic-onset juvenile idiopathic arthritis (SoJIA) patients, which resulted in a poor or fair clinical response [10]. is associated with a higher expression of IFN response genes [9]. The in vivo IFN bioactivity was determined by the measurement of the expression of type I IFN response genes in the peripheral blood cells. Similar findings were 
made for patients with primary Sjögren syndrome (SS) who were treated with a TNF antagonist [11] in which no evidence of efficacy of infliximab was observed [12]. Here, the type I IFN bioactivity in the blood was measured in an indirect manner, based on the use of a bioassay in which a serum sample is tested to induce the expression of IFN response activity.

Since the finding of an increased IFN response gene activity after TNF blockade was based on studies in diseases in which the clinical response to therapy was shown not to be optimal, we were interested to know whether this effect also applied to diseases that showed a good clinical response. Therefore, we aimed to determine the effect of TNF blockade on the type I IFN response gene activity in RA patients, for approximately two thirds of whom TNF-blocking therapy is effective. Previously, we and others demonstrated increased type I IFN response gene activity in the peripheral blood cells of approximately $50 \%$ of anti-TNF treatment-naive RA patients [13]. This analysis was based on the measurement of the expression of a set of 34 type I IFN response genes. Accordingly, others demonstrated increased levels of IFN $\alpha$ in serum of a subset of RA patients [14]. Here, we first studied whether TNF blockade in RA led to a consistent increase in type I IFN response gene activity as was reported for SoJIA and SS. Subsequently, we determined whether anti-TNF-induced changes in IFN response activity were associated with the clinical outcome of TNF blockade in RA.

\section{Materials and methods \\ Patients}

Consecutive patients with RA according to the American College of Rheumatology criteria were enrolled in the study at the outpatient clinic of the Academic Medical Center (AMC) in Amsterdam over a period of 1 year. Inclusion criteria were 18 to 85 years of age, a failure of at least two disease-modifying anti-rheumatic drugs (including methotrexate [MTX]), and active disease (disease activity score using 28 joint counts [DAS28] of at least 3.2). Patients with a history of an acute inflammatory joint disease of different origin or previous use of a TNF-blocking agent were excluded. Patients were on stable, maximally tolerable MTX treatment. Whole blood samples $(2.5 \mathrm{~mL})$ were obtained using PAXgene tubes (PreAnalytiX GmbH, Hilden, Germany) from 33 RA patients prior to initiation of anti-TNF therapy with infliximab $(3 \mathrm{mg} / \mathrm{kg}$ intravenously at baseline and weeks 2 and 6 and subsequently every 8 weeks). After 4, 8, 12, and 16 weeks of treatment, another PAXgene tube was obtained. All patients gave written informed consent, and the study protocol was approved by the Medical Ethics Committee (AMC). After 16 weeks of treatment, clinical response was assessed using the European League Against Rheumatism (EULAR) response criteria [15,16]

Table 1: Characteristics of patients at baseline

\begin{tabular}{lcc}
\hline & $\begin{array}{c}\text { Array analysis } \\
(\mathbf{n}=\mathbf{1 5})\end{array}$ & $\begin{array}{c}\text { qPCR analysis } \\
\text { (n= 18) }\end{array}$ \\
\hline Age, years & $51(39-55)$ & $58(51-69)$ \\
Gender, female/male & $7 / 8$ & $14 / 4$ \\
Disease characteristics & & $5.7(5.0-6.6)$ \\
DAS28 & $5.6(4.6-7.0)$ & $13(5-44)$ \\
C-reactive protein, mg/dL & $8(6-22)$ & $32(16-47)$ \\
Erythrocyte sedimentation rate & $25(12-41)$ & $541(121-1,805)$ \\
ACPA titer, U/mL & $100(15-595)$ & $67(22-182)$ \\
IgM RF titer, U/mL & $28(14-133)$ & $65(36-1,992)$ \\
Disease duration, months & $77(29-240)$ & $\mathrm{n}=15$ \\
Erosions & $\mathrm{n}=13$ & $21(15-25)$ \\
Medication & & $\mathrm{n}=5$ \\
Methotrexate dose, mg/week & $25(20-30)$ & $\mathrm{n}=12$ \\
Prednisone & $\mathrm{n}=2$ & $\mathrm{n}=7$ \\
NSAID & &
\end{tabular}

Values are presented as median (interquartile range 25 to 75 ) unless indicated otherwise. ACPA, anti-citrullinated protein antibodies; DAS28, disease activity score using 28 joint counts; NSAID, nonsteroidal anti-inflammatory drug; qPCR, quantitative polymerase chain reaction; RF, rheumatoid factor. 
as well as the reduction in DAS28 (response defined by a decrease in DAS28 of at least 1.2) [17]. According to the EULAR response criteria, 6 of the 33 patients had a poor response whereas 12 patients displayed a good response to treatment. An overview of the patients' characteristics is presented in Table 1.

\section{Blood sampling for RNA isolation}

Blood $(2.5 \mathrm{~mL})$ was drawn in PAXgene blood RNA isolation tubes (PreAnalytiX $\mathrm{GmbH}$ ) and stored at $-20^{\circ} \mathrm{C}$. Tubes were thawed for 2 hours at room temperature prior to RNA isolation. Next, total RNA was isolated using the PAXgene RNA isolation kit according to the manufacturer's instructions, including a DNAse (Qiagen, Venlo, The Netherlands) step to remove genomic DNA. Quantity and purity of the RNA were tested using the NanoDrop spectrophotometer (NanoDrop Technologies, Inc., Wilmington, DE, USA).

\section{Microarray data}

In 15 patients, the baseline expression of type I IFN-regulated genes was determined using cDNA microarrays and compared with levels 1 month after treatment. Therefore, we used $43 \mathrm{~K}$ cDNA microarrays (from the Stanford Functional Genomics Facility [18]) printed on aminosilane-coated slides containing approximately 20,000 unique genes. DNA spots were UV-crosslinked to the slide using 150 to $300 \mathrm{~mJ}$. Sample preparation and microarray hybridization were performed as described previously $[13,19]$. Data storage and filtering were performed using the Stanford Microarray Database [20,21] as described previously [22]. Raw data $(\log 2)$ can be downloaded from the publicly accessible Stanford database website [21]. In addition, data are stored in the Gene Expression Omnibus [23] [GEO:GSE19821].

\section{Interferon response gene set}

Previously, we showed that a prominent cluster of highly correlated type I IFN response genes is upregulated in a subgroup of biological-naive RA patients compared with healthy controls [13]. A gene set consisting of 34 type I IFN response genes was obtained from these data. A smaller IFN gene set consisting of 15 genes was selected for validation analysis using a BioMark ${ }^{\mathrm{TM}}$ Real-Time PCR [Polymerase Chain Reaction] System (Fluidigm Corporation, South San Francisco, CA, USA). Detailed information of the gene lists is presented in Table 2 .

\section{Real-time quantitative polymerase chain reaction}

RNA $(0.5 \mu \mathrm{g})$ was reverse-transcribed into cDNA using the Revertaid H-minus cDNA synthesis kit (MBI Fermentas, St. Leon-Rot, Germany) according to the manufacturer's instructions. Real-time quantitative PCR (qPCR) was performed using an ABI Prism 7900HT
Sequence detection system (Applied Biosystems, Foster City, CA, USA) using SybrGreen (Applied Biosystems). Primers were designed using Primer Express software and guidelines (Applied Biosystems), and used primer sequences are listed in Additional file 1. To calculate arbitrary values of mRNA levels and to correct for differences in primer efficiencies, a standard curve was constructed. Expression levels of target genes were expressed relative to $18 S R N A$.

\section{BioMark $^{\mathrm{TM}}$ Real-Time PCR System}

The BioMark ${ }^{\mathrm{TM}} 48.48$ Dynamic Array (Fluidigm Corporation) for real-time qPCR was used to simultaneously measure the expression of 15 IFN response genes (Table 2) in 47 samples (plus one negative control) in triplicate. The 47 samples were derived from 10 patients (five poor and five good EULAR responders) at baseline and 1, 2, 3, or 4 months after treatment. From two poor and one good responder patients, the 3 -month time points are missing. This experiment was performed at the outsourcing company ServiceXS (Leiden, The Netherlands). Used pre-designed Taqman Gene Expression Assays are listed in Additional file 1. Expression levels of target genes were expressed relative to $18 S R N A$.

\section{Statistical analysis}

Data were analyzed using software programs GraphPad Prism 4 (GraphPad Software, Inc., San Diego, CA, USA) and SPSS version 14.0 (SPSS Inc., Chicago, IL, USA). Data were checked for normal (Gaussian) distribution. Paired $t$ test analysis was used to compare pre- and posttreatment expression levels. Two-group comparisons were analyzed using unpaired $t$ test or two-way analysis of variance (ANOVA), where appropriate. Data were considered significant with $P$ values of less than 0.05 .

\section{Results}

\section{Differential effect of tumor necrosis factor blockade on} type I interferon signature

Previously, we compared the gene expression profiles of peripheral blood cells of RA patients with those of healthy controls and found that a subgroup of RA patients has an increased expression of type I IFN response genes [13]. This increased expression in IFN response genes was highly variable between the individual RA patients and unrelated to medication and disease activity. In the present study, we studied the effect of TNF blockade on the transcription of type I IFN response genes. Therefore, we used the expression values of 34 type I IFN response genes (Table 2) (described previously [13]), which were averaged. Subsequently, baseline values were compared with post-treatment levels (Additional file 2). At the patient group level, there was no significant change in type I IFN response gene activity (Figure 1a). 
Table 2: Interferon response gene/transcript sets used in this study

\begin{tabular}{|c|c|c|c|c|}
\hline $\begin{array}{l}\text { IFN set } \\
\text { (34 genes) }\end{array}$ & $\begin{array}{l}\text { Validation } \\
\text { (15 genes) }\end{array}$ & Symbol & $\begin{array}{l}\text { NCBI mRNA accession } \\
\text { number }\end{array}$ & Name \\
\hline $\mathrm{x}$ & & AA075725 & AA075725.1 & None \\
\hline$x$ & & AA142842 & AA142842.1 & None \\
\hline$x$ & & Al347124 & Al347124.1 & None \\
\hline $\mathrm{x}$ & & ATF3 & NM_001030287 & Activating transcription factor 3 \\
\hline $\mathrm{x}$ & & EIF2AK2 & NM_001135651 & Eukaryotic translation initiation factor 2-alpha kinase 2 \\
\hline $\mathrm{x}$ & $x$ & EPSTI1 & NM_001002264 & Epithelial stromal interaction 1 (breast) \\
\hline$x$ & & Hs.128576 & NM_001135993 & CDNA FLJ90394 fis, clone NT2RP2005632 \\
\hline$x$ & & Hs.97872 & Al821640 & Transcribed locus \\
\hline $\mathrm{x}$ & & $\mathrm{IFI} 16$ & NM_005531 & Interferon, gamma-inducible protein 16 \\
\hline $\mathrm{x}$ & $\mathrm{x}$ & IFI35 & NM_005533 & Interferon-induced protein 35 \\
\hline $\mathrm{x}$ & $\mathrm{x}$ & IFI44L & NM_006820 & Interferon-induced protein 44 -like \\
\hline$x$ & $x$ & IFI6 & NM_002038 & Interferon, alpha-inducible protein 6 \\
\hline $\mathrm{x}$ & $x$ & IFIT1 & NM_001548 & $\begin{array}{l}\text { Interferon-induced protein with tetratricopeptide } \\
\text { repeats } 1\end{array}$ \\
\hline$x$ & & IFIT2 & NM_001547 & $\begin{array}{l}\text { Interferon-induced protein with tetratricopeptide } \\
\text { repeats } 2\end{array}$ \\
\hline$x$ & $x$ & IFITM1 & NM_003641 & Interferon-induced transmembrane protein 1 (9-27) \\
\hline$x$ & & IL1RN & NM_000577 & Interleukin 1 receptor antagonist \\
\hline$x$ & $\mathrm{x}$ & IRF2 & NM_002199 & Interferon regulatory factor 2 \\
\hline$x$ & & IRF7 & NM_001572 & Interferon regulatory factor 7 \\
\hline $\mathrm{x}$ & $\mathrm{x}$ & ISG15 & NM_005101 & ISG15 ubiquitin-like modifier \\
\hline $\mathrm{X}$ & $\mathrm{x}$ & LGALS3BP & NM_005567 & Lectin, galactoside-binding, soluble, 3 binding protein \\
\hline$x$ & & MX1 & NM_001144925 & Myxovirus (influenza virus) resistance 1 \\
\hline$x$ & $x$ & $M \times 2$ & NM_002463 & Myxovirus (influenza virus) resistance 2 (mouse) \\
\hline $\mathrm{x}$ & $\mathrm{x}$ & OAS1 & NM_001032409 & 2',5' -oligoadenylate synthetase $1,40 / 46 \mathrm{kDa}$ \\
\hline $\mathrm{x}$ & $x$ & OAS2 & NM_001032731 & 2 ' -5' -oligoadenylate synthetase $2,69 / 71 \mathrm{kDa}$ \\
\hline $\mathrm{x}$ & & PARP14 & NM_017554 & Poly (ADP-ribose) polymerase family, member 14 \\
\hline $\mathrm{x}$ & & PLSCR1 & NM_021105 & Phospholipid scramblase 1 \\
\hline $\mathrm{x}$ & & RNF213 & NM_020914 & Ring finger protein 213 \\
\hline$x$ & $x$ & RSAD2 & NM_080657 & $\begin{array}{l}\text { Radical S-adenosyl methionine domain containing } 2 \\
\text { (alias cig5) }\end{array}$ \\
\hline $\mathrm{x}$ & & RTP4 & NM_022147 & Receptor (chemosensory) transporter protein 4 \\
\hline$x$ & $x$ & SAMD9L & NM_152703 & Sterile alpha motif domain containing 9-like \\
\hline$x$ & $x$ & SERPING1 & NM_000062 & $\begin{array}{l}\text { Serpin peptidase inhibitor, clade G ( } 1 \text { inhibitor), } \\
\text { member } 1\end{array}$ \\
\hline$x$ & & TAP1 & NM_000593 & $\begin{array}{l}\text { Transporter 1, ATP-binding cassette, sub-family B (MDR/ } \\
\text { TAP) }\end{array}$ \\
\hline $\mathrm{x}$ & & TNFAIP6 & NM_007115 & Tumor necrosis factor, alpha-induced protein 6 \\
\hline$x$ & & UBE2L6 & NM_004223 & Ubiquitin-conjugating enzyme E2L 6 \\
\hline
\end{tabular}

IFN, interferon; NCBI, National Center for Biotechnology Information. 


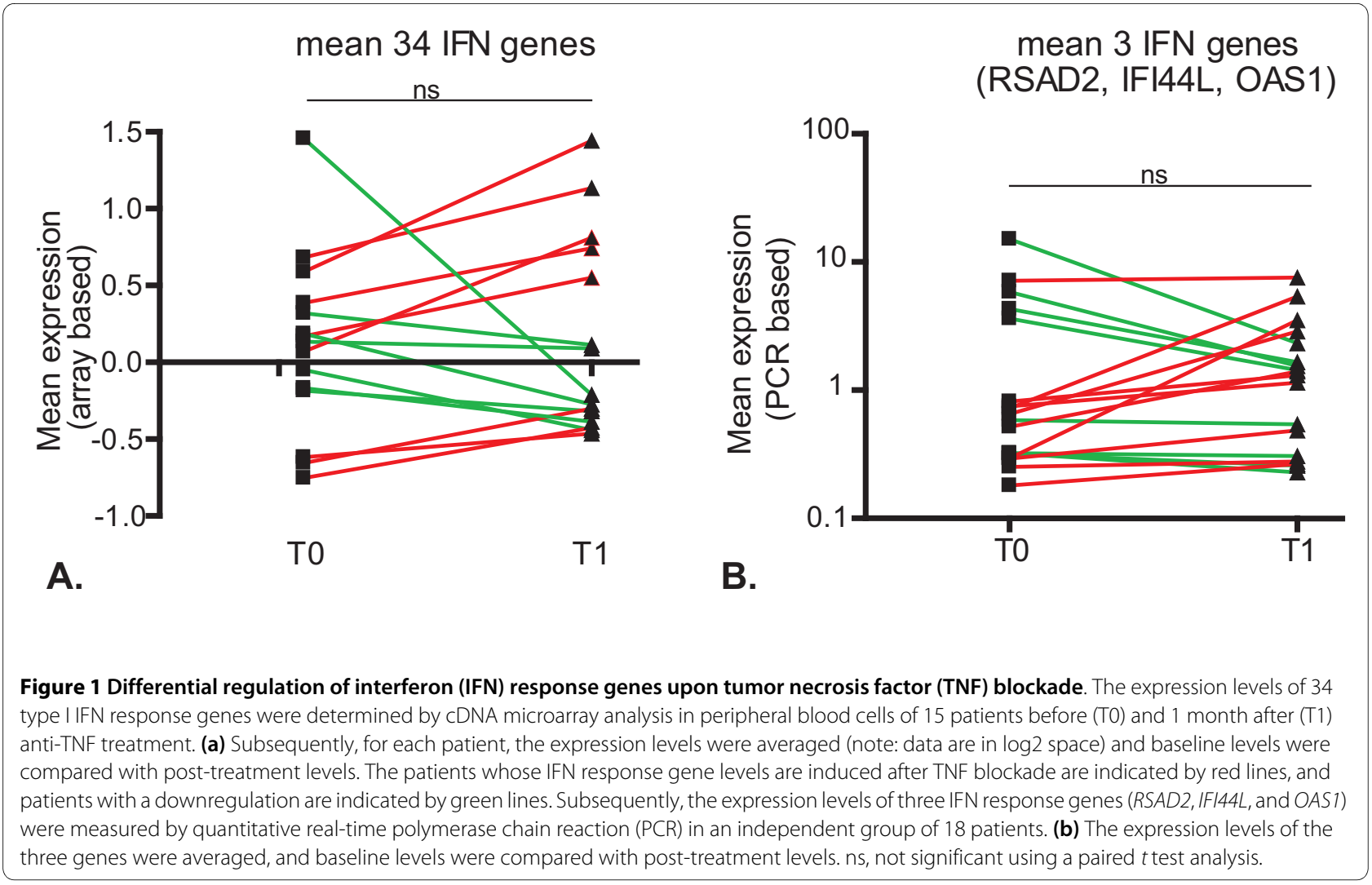

However, the regulation of IFN response genes upon TNF blockade was highly variable between patients. The variation was not related to gender or MTX dose or prednisone or nonsteroidal anti-inflammatory drug (NSAID) use.

To confirm these results in an independent cohort of 18 RA patients, three genes (RSAD2, IFI44L, and OAS1) that showed the best correlation $(\mathrm{R}>0.9)$ with the mean expression value of the set of 34 type I IFN response genes were selected. The mean expression of the three genes was measured by real-time qPCR before and 1 month after infliximab therapy. Ten patients showed an increased expression of these three IFN response genes after TNF blockade, whereas in eight patients similar or decreased levels were observed (Figure 1b). The IFN regulation was independent of gender or MTX dose or prednisolone or NSAID use. Collectively, these results confirm findings from the microarray study and evidently demonstrate that the regulation of IFN response gene activity upon TNF blockade in RA is not as consistent as previously described for SoJIA [9] and SS [11].

\section{Change in type I interferon response gene activity is unrelated to baseline levels}

Since the type I IFN response gene expression levels are already highly heterogeneous in biological-naive RA patients, we investigated whether the observed changes were related to the magnitude of IFN response gene expression prior to treatment. Therefore, the relationship between the extent of the baseline IFN response gene expression levels and its change after TNF blockade was tested. In the 15 patients, the baseline mean expression of the type I IFN gene set did not correlate with their corresponding change after treatment (Pearson $\mathrm{R}=-0.42, P=$ 0.12 ). This was confirmed in the validation group of 18 patients by using the mean expression levels of the three IFN response genes (RSAD2, IFI44L, and OAS1) measured by qPCR, although a trend toward significance was observed (Spearman $\mathrm{R}=-0.44, P=0.064$ ). These findings reveal that the type I IFN response gene expression profile prior to treatment is not associated with the direction of its change upon TNF blockade.

\section{Anti-tumor necrosis factor induced-interferon regulation and clinical response to treatment}

Finally, we investigated whether the treatment-induced changes in type I IFN response gene expression levels were associated with clinical response to treatment. Therefore, the patients $(n=15)$ were divided into two groups on the basis of their change in mean expression level for the 34 IFN response genes (ratio > 1 and ratio < 1) as demonstrated in Figure 1a. Next, clinical parameters were compared between these two groups. Clinical response to treatment was determined after 16 weeks of 


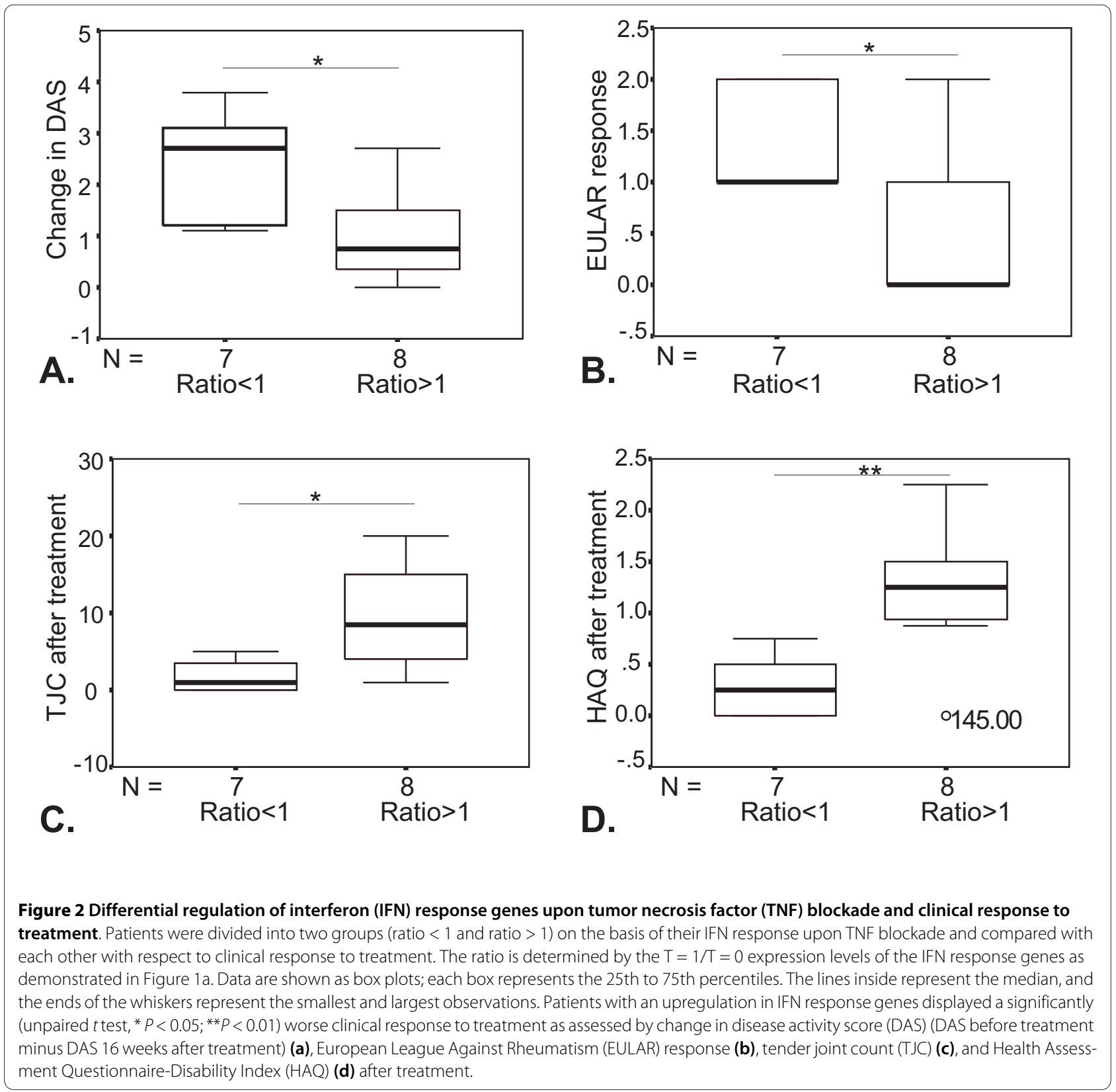

treatment. Interestingly, the patients who showed an increase in type I IFN response gene expression levels after 1 month of treatment had a poor clinical response to treatment. This was reflected by less improvement in disease activity scores $(P=0.013)$ and higher tender joint counts $(P=0.015)$ and higher Health Assessment Questionnaire-Disability Index scores $(P=0.008)$ after treatment (Figure 2). Accordingly, all patients without an antiTNF-induced increase in type I IFN gene activity had a good or moderate response to treatment as assessed by the EULAR response criteria $(P=0.018)$ (Figure 2). From a total of 29 patients, both the EULAR and the qPCR expression data were available for the three IFN response genes RSAD2, IFI44L, and OAS1. Analysis of the pre- versus post-treatment ration of $O A S 1$ revealed that the change in gene expression of OAS1 is significantly associated with clinical response to treatment $(P<0.013)$.

To determine whether the IFN response to TNF blockade was sustained over time, five EULAR good and five EULAR poor responders were selected and the expression levels of 15 IFN response genes (selected from the set of 34 genes used above, Table 2) were measured at baseline and 1, 2, 3, and 4 months after treatment by qPCR (Additional file 3). The expression levels were averaged for the individual patients, and the treatmentinduced changes (ratio post- versus pre-treatment) in 


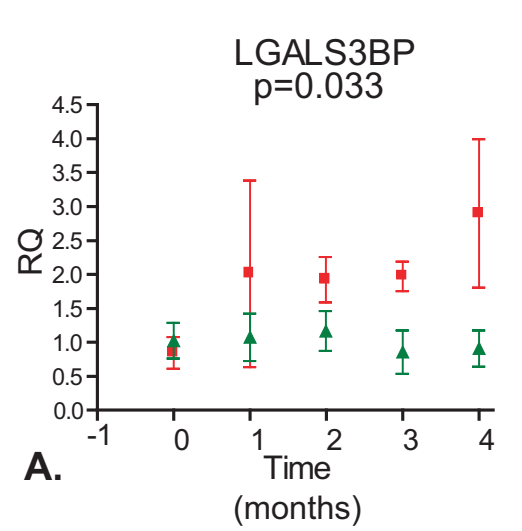

- EULAR 0

$\triangle$ EULAR 2
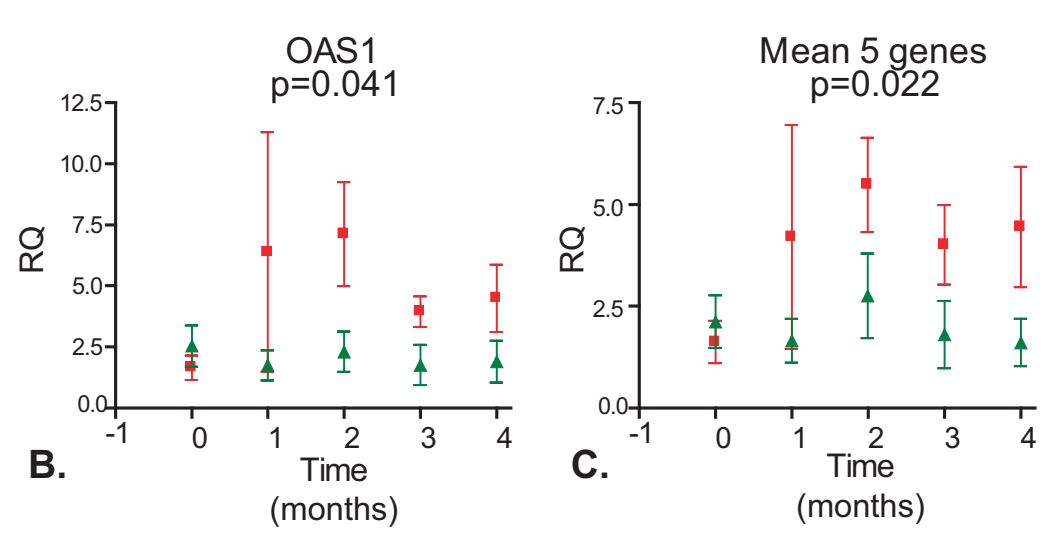

Figure 3 Poor response to tumor necrosis factor blockade is accompanied by upregulation of interferon (IFN) response genes. For five European League Against Rheumatism (EULAR) (0) poor responder (red) and five EULAR (2) good responder (green) patients, the expression levels of 15 IFN response genes were measured by quantitative real-time polymerase chain reaction (PCR) (BioMark ${ }^{\mathrm{TM}}$ ) at baseline and 1, 2, 3, and 4 months after treatment. From two poor and one good responder patients, the 3-month time points are missing. The IFN response gene expression levels during treatment were compared between the two clinical response groups by means of two-way analysis of variance test. Treatment-induced changes in the expression levels of two genes, $L G A L S 3 B P(\mathbf{a})$ and $O A S 1$ (b), were significantly different between the two response groups. (c) The mean expression level of five IFN response genes ( $L G A L S 3 B P, O A S 1, M \times 2$, SERPING1, and OAS2) showed the best significant difference between the two clinical response groups. Graphs show the mean and standard error of the mean expression levels for each clinical response group. RQ, relative quantity.

IFN response gene expression levels over time were compared between the two clinical response groups using two-way ANOVA. Overall, the IFN response genes showed an upregulation in the poor responder group, which was most prominent at 2 months after the start of therapy (data not shown). At the single-gene level, the increased expression in poor versus good responders reached significance for the $O A S 1$ and $L G A L S 3 B P$ genes (Figure $3 \mathrm{a}, \mathrm{b})$. For three other IFN response genes $(M x 2$, $O A S 2$, and SERPING1), a trend ( $P=$ approximately 0.06 , data not shown) was observed toward increased expression in the poor responder patients. Combining these five genes (OAS1, LGALS3BP, Mx2, OAS2, and SERPING1) into one IFN response gene set improved the significance (Figure 3c). These data demonstrate that poor response to infliximab treatment is associated with treatmentinduced increase in type I IFN response gene activity.

\section{Discussion}

In this study, we demonstrated that blockade of the inflammatory cytokine TNF in RA patients modulates the expression of IFN response gene activity in a heterogeneous manner. The data revealed that some RA patients display a treatment-induced increased expression of type I IFN response genes whereas others display no effect or a small decrease. We provided evidence that the treatment-induced change in expression levels of IFN response genes is associated with the EULAR response rate at 16 weeks after the start of infliximab treatment. RA patients who revealed an increased IFN response gene expression profile after 1 to 2 months of anti-TNF treatment exhibited a poor clinical response. No association between clinical response to infliximab treatment and baseline IFN response gene activity was found.

IFNs are known for their immune regulatory properties. Previously, we provided evidence for an increased expression of type I IFN response genes in a subset of patients with RA [13]. Upregulation of type I IFN response genes has been reported in peripheral blood cells of (a subset of) patients with other autoimmune diseases, like SLE [1,24-26], dermatomyositis [27], and multiple sclerosis [22]. Type I IFNs (IFN $\alpha \beta$ ) exert broad dual effects on the immune system, reflecting both immunestimulatory and immune-suppressive activities. Immunestimulatory activities relate to the activation of myeloid dendritic cells, chemokines, chemokine receptors, costimulatory molecules (CD40, CD80, and CD86), and humoral responses. Immune-suppressive effects are reflected by Th2 cell skewing and anti-proliferative and pro-apoptotic effects. According to their dual effect on immunity, their role in disease may range from detrimental to beneficial. Although the anti-TNF-induced increase in IFN response activity might be an epiphenomenon related to the effect of TNF blockade, it is tempting to 
speculate on a role of increased IFN bioactivity in the deteriorating clinical effects. The association between an increase in type I IFN response gene activity and poor response to anti-TNF treatment may suggest a harmful role for type I IFN bioactivity in RA or, alternatively, a failed attempt to counter-regulate inflammation.

Clinical experience revealed that a fraction of patients treated with TNF antagonists developed (increased) antidsDNA antibodies, in some cases with a concomitant lupus-like syndrome [28,29]. From a total of 18 of the 33 patients we studied, levels of anti-citrullinated protein antibody, rheumatoid factor, and double-stranded DNA autoantibody, determined before and 24 weeks after TNF blockade, were available. The expression level of IFN response genes was not related to antibody levels at baseline nor was the activation of the IFN response genes related to the drug-induced formation of antibodies (data not shown [30]).

The differences between the effects of TNF blockade on IFN response activity between the studies in SS [11] and SoJIA [9], on the one hand, and our studies in RA and spondyloarthritis (SpA) [31], on the other, could have their origin in differences in design between the studies, such as the use of infliximab in RA versus etanercept in SS, and the different readout systems used. For example, the SS study was based on an indirect reporter cell assay to measure type I IFN activity in plasma, whereas in the SoJIA and RA studies, measurement of IFN response gene activity in the peripheral blood cells was measured. Using the reporter assay, we previously demonstrated that the serum type I IFN bioactivity was increased in SpA patients treated with etanercept whereas it was transiently declined by infliximab [31]. This is suggestive for differential effects of etanercept and infliximab on IFN response activity, although the direct consequence for the IFN response signature in the peripheral blood cells has not been tested. In an attempt to find an explanation for the apparent discrepancies in IFN response gene activity related to clinical response to infliximab, we learned that in both RA and SS [11,12] an increased IFN response activity is associated with a poor clinical response.

The inter-individual differences in anti-TNF-induced IFN response may be the result of differential regulatory processes. Evidence that TNF blockade may exert both inhibitory and activating effects on IFN response activity is available. In vitro experiments suggested that endogenous secretion of TNF by $\mathrm{pDCs}$ represents a negative feedback on IFN production [9]. Whereas this finding suggested that TNF displays counteracting effects on IFN response activity, others have reported that TNF initiates an IRF1-dependent autocrine loop leading to sustained expression of STAT1-dependent type I IFN response genes [32]. Hence, the divergent outcome of the IFN response activity might be a consequence of differences in the relative contribution of each of these processes in the regulation of IFN response activity. Alternatively, genetic variation in the type I IFN biology could underlie the variation in response activity. Single-nucleotide polymorphisms in several transcription factors involved the type I IFN pathway (for example, IRF5, Tyk2, and STAT4) have recently been associated with a number of autoimmune diseases, including SLE [33,34] and RA [35-37]. Future studies are needed to unravel the mechanism behind the divergent alterations in IFN response gene activity upon TNF blockade. Since the current information on the differential IFN response gene activity does not have predictive value to identify responders before the start of therapy, detailed insight in the regulatory processes that underlie this effect might be helpful to identify such biomarkers. Therefore, in vitro studies with blood cells that are treated with a TNF blocker might be useful.

\section{Conclusions}

In summary, this study shows that there is a large variation between RA patients in the change of IFN response gene expression levels during TNF blockade. The change in IFN response genes is unrelated to baseline expression levels. Interestingly, treatment-induced increase of IFN response gene activity is associated with poor clinical response to infliximab treatment. Additional studies in larger patient cohorts should reproduce and confirm these findings.

\section{Additional material}

\section{Additional file 1}

Information on real-time PCR assays. Primer sequences for quantitative real-time PCR and Pre-designed Taqman Gene Expression Assays used for Fluidigm's BioMark ${ }^{\text {TM }}$ Real-Time PCR System.

\section{Additional file 2}

Microarray data values of the individual 34 IFN response genes. Microarray data values (in log2) of the 34 IFN response genes measured in 15 RA patients before and one month after infliximab treatment including EULAR response.

\section{Additional file 3}

qPCR values of the individual 15 IFN response genes. Gene expression values of 15 IFN response genes measured by Fluidigm's BioMark ${ }^{\mathrm{TM}}$ Real-Time PCR System. Expression values were measured before start of treatment, one, two, three and four months after start of therapy in 5 EULAR good responder patients and 5 EULAR poor responder patients.

\section{Abbreviations}

AMC: Academic Medical Center; ANOVA: analysis of variance; DAS28: disease activity score using 28 joint counts; EULAR: European League Against Rheumatism; IFN: interferon; MTX: methotrexate; NSAID: nonsteroidal anti-inflammatory drug; PCR: polymerase chain reaction; PDC: plasmacytoid dendritic cell; qPCR: quantitative polymerase chain reaction; RA: rheumatoid arthritis; SLE: systemic lupus erythematosus; SoJIA: systemic-onset juvenile idiopathic arthritis; SpA: spondyloarthritis; SS: Sjögren syndrome; TNF: tumor necrosis factor. 


\section{Competing interests}

PT has served as a consultant for Abbott (Abbott Park, IL, USA), Amgen (Thousand Oaks, CA, USA), Centocor (Horsham, PA, USA), Schering-Plough Corporation (Kenilworth, NJ, USA), UCB (Brussels, Belgium), and Wyeth (Madison, NJ, USA). The VU University Medical Center has filed a patent application (patent file number P086657EP00, 'Predicting clinical response to treatment with a soluble TNF-antagonist or TNF, or a TNF receptor agonist'). The other authors declare that they have no competing interests.

\section{Authors' contributions}

LVB helped to conceive, design, and perform the experiments, participated in analysis and interpretation of data, and helped to write the paper. CW helped to conceive, design, and perform the experiments, participated in patient inclusion and disease activity measure, and helped to write the paper. PT helped to conceive and design the experiments and participated in patient inclusion and disease activity measure. CV helped to conceive and design the experiments, participated in analysis and interpretation of data, and helped to write the paper. TvdPK participated in analysis and interpretation of data and analysis tools. TC, DB, and BD participated in patient inclusion, disease activity measurements and clinical laboratory analyses. FR helped to perform the experiments. All authors read and approved the final manuscript.

\section{Acknowledgements}

This study was supported by grants from The Netherlands Organization for Health Research and Development (ZonMw) of The Netherlands Organization for Scientific Research (NWO) (grant number 945-02-029), the European Community's FP6 funding (AUTOCURE), the Innovation Oriented research Program (IOP) on Genomics, and the Centre for Medical Systems Biology (Netherlands Genomics Initiative). This publication reflects the views of the authors only. The European Community is not liable for any use that may be made of the information herein. We thank ServiceXS for performing the real-time PCR experiments using Dynamic Array on the BioMark ${ }^{\mathrm{T}}$ instrument (Fluidigm Corporation). This was made possible, in part, via the ServiceXS-Fluidigm Application Challenge prize awarded to LvB.

\section{Author Details}

'Department of Pathology, VU University Medical Center, De Boelelaan 1118, $1081 \mathrm{HZ}$, Amsterdam, The Netherlands,

${ }^{2}$ Current address: Department of Clinical Immunology \& Rheumatology, Academic Medical Center, University of Amsterdam, Meibergdreef 9, 1105 AZ, Amsterdam, The Netherlands,

${ }^{3}$ Department of Clinical Immunology \& Rheumatology, Academic Medical Center, University of Amsterdam, Meibergdreef 9, 1105 AZ, Amsterdam, The Netherlands,

4Department of Molecular Cell Biology \& Immunology, VU University Medical Center, Van der Boechorststraat 7, 1081 BT, Amsterdam, The Netherlands and ${ }^{5}$ Department of Rheumatology, VU University Medical Center, De Boelelaan $1117,1081 \mathrm{HV}$, Amsterdam, The Netherlands

Received: 11 June 2009 Revisions Requested: 27 July 2009 Revised: 10 December 2009 Accepted: 22 January 2010 Published: 22 January 2010

\section{References}

1. Baechler EC, Batliwalla FM, Karypis G, Gaffney PM, Ortmann WA, Espe KJ, Shark KB, Grande WJ, Hughes KM, Kapur V, Gregersen PK, Behrens TW: Interferon-inducible gene expression signature in peripheral blood cells of patients with severe lupus. Proc Natl Acad Sci USA 2003, 100:2610-2615.

2. Baechler EC, Gregersen PK, Behrens TW: The emerging role of interferon in human systemic lupus erythematosus. Curr Opin Immunol 2004, 16:801-807.

3. Ronnblom LE, Alm GV, Oberg KE: Autoimmunity after alpha-interferon therapy for malignant carcinoid tumors. Ann Intern Med 1991 115:178-183.

4. Feldmann M, Maini RN: Anti-TNF alpha therapy of rheumatoid arthritis: what have we learned? Annu Rev Immunol 2001, 19:163-196.

5. Elliott MJ, Maini RN, Feldmann M, Kalden JR, Antoni C, Smolen JS, Leeb B, Breedveld FC, Macfarlane JD, Bijl H: Randomised double-blind comparison of chimeric monoclonal antibody to tumour necrosis factor alpha (cA2) versus placebo in rheumatoid arthritis. Lancet 1994, 344:1105-1110.

6. Targan SR, Hanauer SB, van Deventer SJ, Mayer L, Present DH, Braakman T, DeWoody KL, Schaible TF, Rutgeerts PJ: A short-term study of chimeric monoclonal antibody CA2 to tumor necrosis factor alpha for Crohn's disease. Crohn's Disease cA2 Study Group. N Eng/ J Med 1997, 337:1029-1035.

7. Tracey D, Klareskog L, Sasso EH, Salfeld JG, Tak PP: Tumor necrosis factor antagonist mechanisms of action: a comprehensive review. Pharmacol Ther 2008, 117:244-279.

8. Banchereau J, Pascual V, Palucka AK: Autoimmunity through cytokineinduced dendritic cell activation. Immunity 2004, 20:539-550.

9. Palucka AK, Blanck JP, Bennett L, Pascual V, Banchereau J. Crossregulation of TNF and IFN-alpha in autoimmune diseases. Proc Natl Acad Sci USA 2005, 102:3372-3377.

10. Kimura Y, Pinho P, Walco G, Higgins G, Hummell D, Szer I, Henrickson M, Watcher $S$, Reiff A: Etanercept treatment in patients with refractory systemic onset juvenile rheumatoid arthritis. J Rheumatol 2005, 32:935-942

11. Mavragani CP, Niewold TB, Moutsopoulos NM, Pillemer SR, Wahl SM, Crow MK: Augmented interferon-alpha pathway activation in patients with Sjogren's syndrome treated with etanercept. Arthritis Rheum 2007, 56:3995-4004.

12. Mariette X, Ravaud P, Steinfeld S, Baron G, Goetz J, Hachulla E, Combe B, Puechal X, Pennec Y, Sauvezie B, Perdriger A, Hayem G, Janin A, Sibilia J: Inefficacy of infliximab in primary Sjogren's syndrome: results of the randomized, controlled Trial of Remicade in Primary Sjogren's Syndrome (TRIPSS). Arthritis Rheum 2004, 50:1270-1276.

13. Pouw Kraan $T C$ van der, Wijbrandts $C A$, van Baarsen $L G$, Voskuyl $A E$, Rustenburg F, Baggen JM, Ibrahim SM, Fero M, Dijkmans BA, Tak PP, Verweij CL: Rheumatoid arthritis subtypes identified by genomic profiling of peripheral blood cells: assignment of a type I interferon signature in a subpopulation of patients. Ann Rheum Dis 2007, 66:1008-1014

14. Bokarewa M, Tarkowski A, Lind M, Dahlberg L, Magnusson M: Arthritogenic dsRNA is present in synovial fluid from rheumatoid arthritis patients with an erosive disease course. Eur J Immunol 2008, 38:3237-3244

15. van Gestel AM, Prevoo ML, van 't Hof MA, van Rijswijk MH, Putte LB van de, van Riel PL: Development and validation of the European League Against Rheumatism response criteria for rheumatoid arthritis. Comparison with the preliminary American College of Rheumatology and the World Health Organization/International League Against Rheumatism Criteria. Arthritis Rheum 1996, 39:34-40.

16. Fransen J, van Riel PL: The Disease Activity Score and the EULAR response criteria. Clin Exp Rheumatol 2005, 23:S93-S99.

17. van Gestel AM, Haagsma CJ, van Riel PL: Validation of rheumatoid arthritis improvement criteria that include simplified joint counts. Arthritis Rheum 1998, 41:1845-1850.

18. Stanford: functional genomics facility [http://microarray.org/sfaf/

19. Pouw Kraan TC van der, van Baarsen LG, Rustenburg F, Baltus B, Fero M, Verweij CL: Gene expression profiling in rheumatology. Methods $\mathrm{Mol}$ Med 2007, 136:305-327.

20. Demeter J, Beauheim C, Gollub J, Hernandez-Boussard T, Jin H, Maier D, Matese JC, Nitzberg M, Wymore F, Zachariah ZK, Brown PO, Sherlock G, Ball CA: The Stanford Microarray Database: implementation of new analysis tools and open source release of software. Nucleic Acids Res 2007, 35:D766-D770.

21. Stanford Microarray Database [http://smd.stanford.edu/]

22. van Baarsen $L G$, Pouw Kraan TC van der, Kragt JJ, Baggen JM, Rustenburg F, Hooper T, Meilof JF, Fero MJ, Dijkstra CD, Polman CH, Verweij CL: A subtype of multiple sclerosis defined by an activated immune defense program. Genes Immun 2006, 7:522-531.

23. Gene Expression Omnibus [http://www.ncbi.nlm.nih.gov/geo

24. Bennett L, Palucka AK, Arce E, Cantrell V, Borvak J, Banchereau J, Pascual V: Interferon and granulopoiesis signatures in systemic lupus erythematosus blood. J Exp Med 2003, 197:711-723.

25. Han GM, Chen SL, Shen N, Ye S, Bao CD, Gu YY: Analysis of gene expression profiles in human systemic lupus erythematosus using oligonucleotide microarray. Genes Immun 2003, 4:177-186.

26. Kirou KA, Lee C, George S, Louca K, Peterson MG, Crow MK: Activation of the interferon-alpha pathway identifies a subgroup of systemic lupus 
erythematosus patients with distinct serologic features and active disease. Arthritis Rheum 2005, 52:1491-1503.

27. Baechler EC, Bauer JW, Slattery CA, Ortmann WA, Espe KJ, Novitzke J, Ytterberg SR, Gregersen PK, Behrens TW, Reed AM: An interferon signature in the peripheral blood of dermatomyositis patients is associated with disease activity. Mol Med 2007, 13:59-68.

28. Charles PJ, Smeenk RJ, De Jong J, Feldmann M, Maini RN: Assessment of antibodies to double-stranded DNA induced in rheumatoid arthritis patients following treatment with infliximab, a monoclonal antibody to tumor necrosis factor alpha: findings in open-label and randomized placebo-controlled trials. Arthritis Rheum 2000, 43:2383-2390.

29. Maini RN, Elliott MJ, Charles PJ, Feldmann M: Immunological intervention reveals reciprocal roles for tumor necrosis factor-alpha and interleukin-10 in rheumatoid arthritis and systemic lupus erythematosus. Springer Semin Immunopathol 1994, 16:327-336.

30. Cantaert T, van Baarsen EGM, Wijbrandts CA, Thurlings RM, Sande MG van de, Bos C, Pouw Kraan TCTM van der, Verweij CL, Tak PP, Baeten D: Type I interferons have no major influence on humoral autoimmunity in rheumatoid arthritis. Rheumatology 2009 in press.

31. Cantaert T, De Rycke L, Mavragani CP, Wijbrandts CA, Niewold TB, Niers T, Vandooren B, Veys EM, Richel D, Tak PP, Crow MK, Baeten D: Exposure to nuclear antigens contributes to the induction of humoral autoimmunity during TNF alpha blockade. Ann Rheum Dis 2008, 68:1022-1029

32. Yarilina A, Park-Min KH, Antoniv T, Hu X, Ivashkiv LB: TNF activates an IRF1-dependent autocrine loop leading to sustained expression of chemokines and STAT1-dependent type I interferon-response genes. Nat Immunol 2008, 9:378-387.

33. Sigurdsson S, Nordmark G, Goring HH, Lindroos K, Wiman AC, Sturfelt $G$, Jonsen A, Rantapaa-Dahlqvist S, Moller B, Kere J, Koskenmies S, Widen E, Eloranta ML, Julkunen H, Kristjansdottir H, Steinsson K, Alm G, Ronnblom $L$, Syvanen AC: Polymorphisms in the tyrosine kinase 2 and interferon regulatory factor 5 genes are associated with systemic lupus erythematosus. Am J Hum Genet 2005, 76:528-537.

34. Sigurdsson S, Nordmark G, Garnier S, Grundberg E, Kwan T, Nilsson O, Eloranta ML, Gunnarsson I, Svenungsson E, Sturfelt G, Bengtsson AA, Jonsen A, Truedsson L, Rantapaa-Dahlqvist S, Eriksson C, Alm G, Goring $\mathrm{HH}$, Pastinen T, Syvanen AC, Ronnblom L: A risk haplotype of STAT4 for systemic lupus erythematosus is over-expressed, correlates with antidsDNA and shows additive effects with two risk alleles of IRF5. Hum Mol Genet 2008, 17:2868-2876

35. Remmers EF, Plenge RM, Lee AT, Graham RR, Hom G, Behrens TW, de Bakker PI, Le JM, Lee HS, Batliwalla F, Li W, Masters SL, Booty MG, Carulli JP, Padyukov L, Alfredsson L, Klareskog L, Chen WV, Amos Cl, Criswell LA, Seldin MF, Kastner DL, Gregersen PK: STAT4 and the risk of rheumatoid arthritis and systemic lupus erythematosus. N Engl J Med 2007, 357:977-986.

36. Dieguez-Gonzalez R, Calaza M, Perez-Pampin E, de la Serna AR, FernandezGutierrez B, Castaneda S, Largo R, Joven B, Narvaez J, Navarro F, Marenco JL, Vicario JL, Blanco FJ, Fernandez-Lopez JC, Caliz R, Collado-Escobar MD, Carreno L, Lopez-Longo J, Canete JD, Gomez-Reino JJ, Gonzalez A: Association of interferon regulatory factor 5 haplotypes, similar to that found in systemic lupus erythematosus, in a large subgroup of patients with rheumatoid arthritis. Arthritis Rheum 2008, 58:1264-1274.

37. Sigurdsson S, Padyukov L, Kurreeman FA, Liljedahl U, Wiman AC, Alfredsson L, Toes R, Ronnelid J, Klareskog L, Huizinga TW, Alm G, Syvanen $A C$, Ronnblom L: Association of a haplotype in the promoter region of the interferon regulatory factor 5 gene with rheumatoid arthritis. Arthritis Rheum 2007, 56:2202-2210.

doi: $10.1186 /$ ar2912

Cite this article as: van Baarsen et al., Regulation of IFN response gene activity during infliximab treatment in rheumatoid arthritis is associated with clinical response to treatment Arthritis Research \& Therapy 2010, 12:R11

\section{Submit your next manuscript to BioMed Centra} and take full advantage of:

- Convenient online submission

- Thorough peer review

- No space constraints or color figure charges

- Immediate publication on acceptance

- Inclusion in PubMed, CAS, Scopus and Google Scholar

- Research which is freely available for redistribution

Submit your manuscript at www.biomedcentral.com/submit
C BioMed Central 